TITLE:

\title{
ECOLOGY OF SHALLOW-WATER FORAMINIFERA OFF THE COAST OF NOBORIBETSU, SOUTHWESTERN HOKKAIDO, JAPAN
}

\author{
$\operatorname{AUTHOR}(\mathrm{S})$ : \\ Uchio, Takayasu
}

\section{CITATION:}

Uchio, Takayasu. ECOLOGY OF SHALLOW-WATER FORAMINIFERA OFF THE COAST OF NOBORIBETSU, SOUTHWESTERN HOKKAIDO, JAPAN. PUBLICATIONS OF THE SETO MARINE BIOLOGICAL LABORATORY 1959, 7(3): 295-302

ISSUE DATE:

1959-12-20

URL:

http://hdl.handle.net/2433/174639

RIGHT: 


\title{
ECOLOGY OF SHALLOW-WATER FORAMINIFERA OFF THE COAST OF NOBORIBETSU, SOUTHWESTERN HOKKAIDO, JAPAN
}

TAKAYASU UCHIO

\author{
Petroleum Engineering Inst., University of Tokyo
}

With 3 Text-figures and 2 Tables

\section{Introduction}

In the late summer of 1958 , eleven bottom sediments were collected off the coast of Noboribetsu, near Muroran, Hokkaido, by the members of the Japanese Hydrographic Office. The locations, depths, types of sediments and dates of collection of these samples are listed in Table 1 and are shown in Fig. 1.

The sediments were collected by using a dredge, dried on the survey ship. They were dried in an electric oven for a few hours, weighed, then washed by running water through 250 -mesh sieve (diameter of the opening is $0.06 \mathrm{~mm}$ ) in the laboratory. The part retained on the 250-mesh sieve was placed in an evaporating dish, dried in an oven. Foraminifera were floated from the dried sediment by using $\mathrm{CCl}_{4}$ according to the method developed by Y. OzAwA at the Cushman Laboratory (CusHman, 1940 , p. 27). All of floated and unfloated specimens of each sample were analyzed for species quantitatively. Therefore, the Foraminifera assemblages here dealt with are thanatocoenoses, which may include a few living specimens.

The writer wishes to express his cordial thanks to Messrs. Ryoji SekizukA, Shigeru MOGI and Ninko SATo of the Japanese Hydrographic Office for submitting the material to the writer's disposal; to Prof. Tomofusa Mitsuchi of the University of Tokyo and to Prof. Takasi TokiokA of the University of Kyoto for their constant encouragement and advice.

\section{Submarine Topography and Geology}

According to the Hydrographic Chart 17 published by the Japanese Hydrographic Office, the submarine topography of this area is simple (see Fig. 1). There is a narrow (ca. $15 \mathrm{~km}$ wide) continental shelf down to a depth of $c a .100 \mathrm{~m}$. The shelf can be divided into two parts. The inner one is a narrow ( $c a .3 .5 \mathrm{~km}$ wide), rather

Publ. Seto Mar. Biol. Lab., VII (3), 1959. (Article 17) 
steeply sloping $\left(\mathrm{ca} .0^{\circ} 35^{\prime}\right)$ zone, the lower edge of which lies at a depth of 50-60 m. The outer one is an almost horizontal terrace. These characters show that the continental shelf of this area is in close agreement with SHEPARD's statistics (1948, p. 144) that the average slope is $0^{\circ} 07^{\prime}$, being somewhat steeper in the inner half than the outer half.

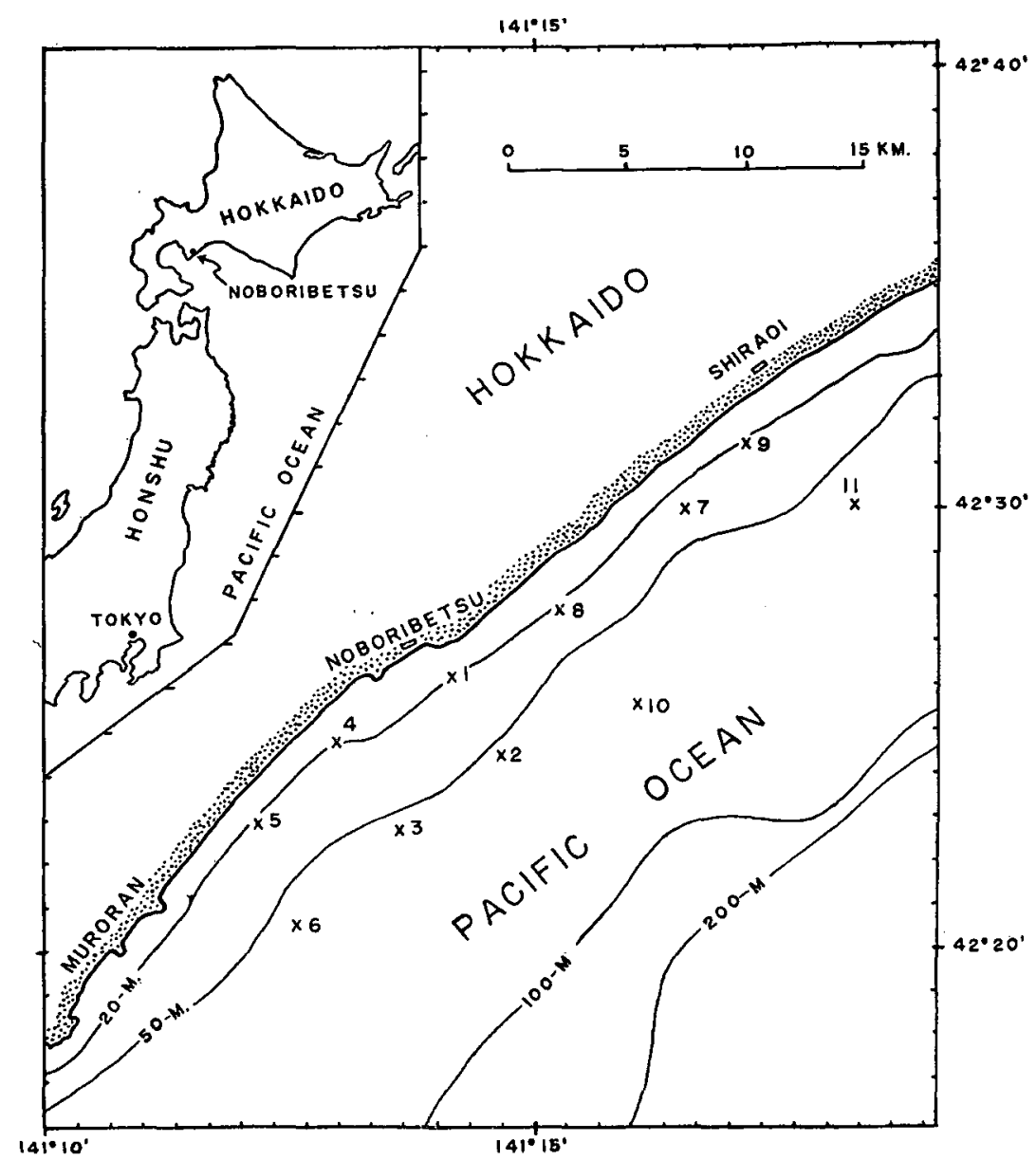

Fig. 1. Locations of stations and the submarine topography of the area.

The bottom shallower than $20 \mathrm{~m}$ is covered by sand, and the deeper part by silty sand (mud and sand in Table 1) or silt (mud in Table 1). Frequently these sediments contain a rather large quantity of pumice grain (except at Stations 3 and 4), and also plant fragments to a lesser extent. Acila (Truncacila) insignis (GoulD) is abundant at Station 5, where both (right and left) valves of each individual were tied firmly together. This indicates that the fauna at Station $5 \mathrm{might}$ 
Table 1. Locations of stations, depths, types of sediments, and dates of collections.

\begin{tabular}{|c|c|c|c|c|c|c|c|}
\hline \multirow{2}{*}{ Station } & \multicolumn{2}{|c|}{ Location } & \multirow{2}{*}{$\begin{array}{l}\text { Depth } \\
\text { (m) }\end{array}$} & \multirow{2}{*}{ Sediment } & \multirow{2}{*}{\multicolumn{3}{|c|}{ Date }} \\
\hline & N. Lat. & E. Long. & & & & & \\
\hline 1 & $42^{\circ} 26^{\prime} 11^{\prime \prime}$ & $141^{\circ} 12^{\prime} 27^{\prime \prime}$ & 22 & Sand \& Mud & 1958 & Aug. & 30 \\
\hline 2 & $42^{\circ} 24^{\prime} 24^{\prime \prime}$ & $141^{\circ} 13^{\prime} 54^{\prime \prime}$ & 65 & Mud & 1958 & Aug. & 30 \\
\hline 3 & $42^{\circ} 22^{\prime} 49^{\prime \prime}$ & $141^{\circ} 11^{\prime} 02^{\prime \prime}$ & 59 & Mud & 1958 & Aug. & 30 \\
\hline 4 & $42^{\circ} 24^{\prime} 44^{\prime \prime}$ & $141^{\circ} 08^{\prime} 57^{\prime \prime}$ & 19 & fine Sand & 1958 & Aug. & 30 \\
\hline 5 & $42^{\circ} 22^{\prime} 53^{\prime \prime}$ & $141^{\circ} 06^{\prime} 35^{\prime \prime}$ & 28 & Mud \& Sand & 1958 & Aug. & 30 \\
\hline 6 & $42^{\circ} 20^{\prime} 37^{\prime \prime}$ & $141^{\circ} 07^{\prime} 44^{\prime \prime}$ & 56 & Mud & 1958 & Aug. & 31 \\
\hline 7 & $42^{\circ} 30^{\prime} 02^{\prime \prime}$ & $141^{\circ} 19^{\prime} 38^{\prime \prime}$ & 29 & Sand \& Mud & 1958 & Sept. & 11 \\
\hline 8 & $42^{\circ} 27^{\prime} 45^{\prime \prime}$ & $141^{\circ} 15^{\prime} 52^{\prime}$ & 31 & Sand \& Mud & 1958 & Sept. & 11 \\
\hline 9 & $42^{\circ} 31^{\prime} 30^{\prime \prime}$ & $141^{\circ} 21^{\prime} 35^{\prime \prime}$ & 23 & Pumice & 1958 & Sept. & 14 \\
\hline 10 & $42^{\circ} 25^{\prime} 37^{\prime \prime}$ & $141^{\circ} 18^{\prime} 15^{\prime \prime}$ & 80 & Mud \& Sand & 1958 & Sept. & 15 \\
\hline 11 & $42^{\circ} 30^{\prime} 06^{\prime \prime}$ & $141^{\circ} 24^{\prime} 48^{\prime \prime}$ & 70 & Sand \& Mud & 1958 & Sept. & 23 \\
\hline
\end{tabular}

be deposited in situ. Grain size analysis of these sediments will be made by Ninko SATo of the Japanese Hydrographic Office in the near future.

\section{Hydrography}

Since the Foraminifera assemblages here dealt with are not biocoenoses but thanatocoenoses, there may be no direct relationship between the thanatocoenoses and hydrographic phenomena. Nevertheless, the thanotocoenoses might indirectly be related to the average oceanographic conditions during the past few hundreds or thousands years. It is, therefore, necessary to analyse hydrographic data to understand fully what causes faunal distributions. In the following the writer gives a general picture of the oceanographic conditions in this area and its surroundings.

Very few oceanographic data are available in the area concerned, while so many data have been published in the neighbouring areas every ten days by the Hakodate Marine Observatory and others. The reasons are that this area has importance neither in fishery nor in oceanographic-meteorological observations. There are three surface water masses (warm Tsugaru Current, warm Kuroshio and cold Oyashio) in the general area concerned.

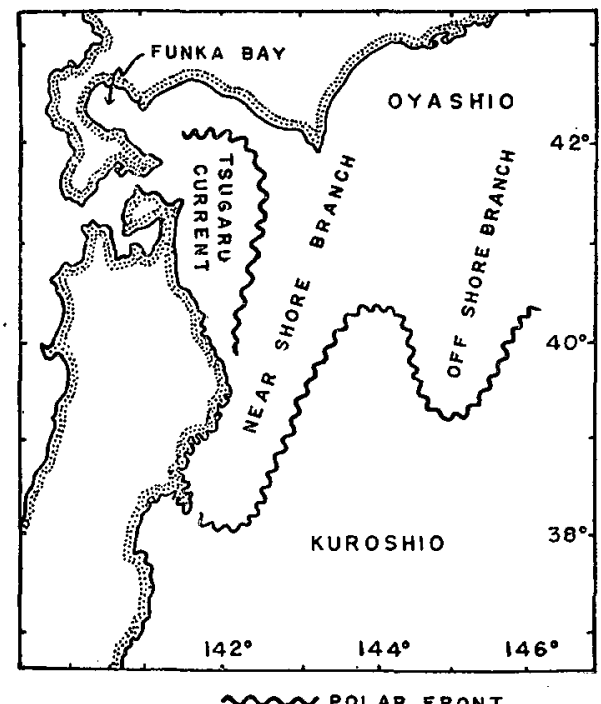

Fig. 2. Generalized pattern of distributions of the three currents in the waters off N.E. Honshû, Japan. 
The seasonal and yearly fluctuations of these water masses determine the oceanographic-meteorologic, faunal and floral patterns of the area. A generalized pattern of distributions of the three currents is shown in Fig. 2. As is shown in Fig. 2, the area here studied is almost always covered by a westerly or northwesterly extension, though much modified by mixing with Tsugaru Current, of the nearshore branch of the subarctic Oyashio, but the warm Tsugaru Current may give influences to the area in summer. Below the Oyashio there lies the Intermediate Water, which is characterized by a salinity minimum (less than 33.8\%). The thickness of the Oyashio is variable locally and not well known. According to UDA (1938) the low salinity and low density Oyashio is about $25 \mathrm{~m}$ in thickness, and between 50 and $150 \mathrm{~m}$ in depth there is the cold Intermediate Water, whose density is high and salinity is nearly constant. He does not mention the layer between 25 and $50 \mathrm{~m}$ in depth, but it appears to be a thermocline.

Fig. 3 shows approximate maximum and minimum water temperatures and salinities in this area in relation to depth according to the results of marine meteorologicaloceanographical observations published by the Central Meteorological Observatory.

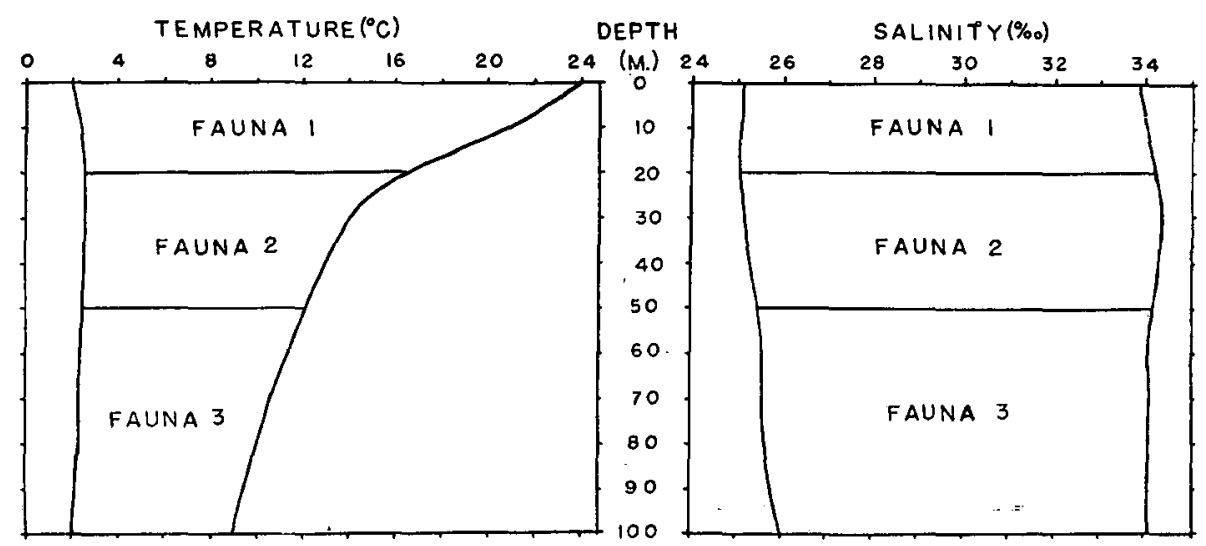

Fig. 3. Maximum and minimum bottom temperatures and salinities in relation to depth.

Maximum temperature of the surface water is $24^{\circ} \mathrm{C}$., which is an extreme during the recent 10 years. The average of maximum temperatures in each year will be about $19-20^{\circ} \mathrm{C}$. In general temperature and salinity are the lowest in January and February and the highest in August and September, and the reverse is true in the case of oxygen content in waters. Amount of the dissolved oxygen in water in this area is $5-8 \mathrm{cc} / \mathrm{L}$ and decrease from the surface toward the deep. The water is oversaturated and sometimes nearly saturated with oxygen within a depth range of $0-100 \mathrm{~m}$.

HIDAKa (1934), from the distributions of temperature and salinity, could find a boundary at about $25 \mathrm{~m}$, which divides waters into two layers along a traverse at the entrance of Funka-wan (Volcanic Bay). Furthermore, he, in the main part of the bay, could find a very distinct boundary at $50 \mathrm{~m}$, above which there are inflow of 
water from the Pacific Ocean into the bay along the southern shore, a horizontal and clockwise gire, a sinking water at the center of the bay, and an upwelling along the shore of the bay, while below which there is an outflow of water from the bay to the Pacific Ocean along the northern shore of the bay. He also pointed out that the water was stagnant below $90 \mathrm{~m}$ in the bay and there was no exchange of water between the bay and Pacific Ocean below that level. Matsudaira and Mizuuchi (1934) reached the same conclusion from the distribution of oxygen, phosphate, silicate and $\mathrm{pH}$.

\section{Foraminifera Depth Assemblages and Boundaries}

The Foraminifera here dealt with are divided into three assemblages, and the deepest one may be subdivided into two. These divisions are based upon the following criteria: shallow and/or deep limit of the various species, and depth range at which the species have the greatest frequency. Occurrences of the species of benthonic Foraminifera are listed in Table 2.

Fauna 1 is represented by only one sample, and more materials are necessary to establish this assemblage. The shallow limit of this assemblage is unknown, and deep one is at depth of $c a .20 \mathrm{~m}$. The assemblage is characterized by predominance of Pseudononion japonicum Asano, and also by Buccella frigida (Cushman).

The boundary at $c a .20 \mathrm{~m}$ is based upon great change in frequency occurrences of Pseudononion japonicum Asano, Eggerella advena Cushman and Elphidium clavatum Cushman.

Fauna 2 is characterized by the predominance of Eggerella advena CusHMAN and Elphidium clavatum Cushman. Pseudononion japonicum Asano, Buccella frigida (Cushman) and Elphidium subarcticum Cushman are also important members of this assemblage.

The boundary at $c a \cdot 40-50 \mathrm{~m}$ is very distinct and is based upon :

1) Nonionella stella Cushman \& Moyer becomes dominant suddenly.

2) Eggerella advena Cushman, Elphidium clavatum Cushman become much less dominant.

3) Pseudononion japonicum Asano, Elphidium subarcticum Cushman, Lagenammina diffulgiformis var. lagenaria (BERTHELIN),. Elphidium oregonensis Cushman \& Grant, Quinqueloculina sp. cf. Q. seminula (Linnaeus) and Streblus japonicus (HADA) become extinct or almost extinct in Fauna 3.

4) Textularia earlandi PARKER, Trochammina squamata stellata HögLUND, Epistominella tamana (KuwANo), Buccella frigida (Cushman) and Reophax communis LACROIX become more abundant in Fauna 3.

5) Trochammina pacifica Cushman, Goësella flintii Cushman, Haplophragmoides bradyi (ROBERTSON), Lagena mollis CusHMAN, Fissurina laevigata Reuss, Uvigerina cushmani ToDD, Virgulina sp., Alveolophragmium crassimargo 
Table 2. Percentage distribution of the benthonic Foraminifera off the coast of Noboribetsu, Hokkaido, Japan.

\begin{tabular}{|c|c|c|c|c|c|c|c|c|c|c|}
\hline Fauna & 1 & & 2 & 2 & & & & $3 \mathrm{~A}$ & & $3 \mathrm{~B}$ \\
\hline Station & 4 & 1 & 5 & 7 & 8 & 6 & 3 & 2 & 11 & 10 \\
\hline Depth (m) & 19 & 22 & 28 & 29 & 31 & 56 & 59 & 65 & 70 & 80 \\
\hline Pseudnonion japonicum ............ & 68 & 14 & 20 & 12 & 20 & - & $x$ & - & - & - \\
\hline Buccella frigida ..................... & 14 & 10 & 9 & 5 & 6 & 8 & 2 & $x$ & 8 & 3 \\
\hline Elphidium subarcticum........... & 5 & 14 & 3 & 3 & 3 & - & - & - & 1 & $x$ \\
\hline Elphidium clavatum $\quad$ …........... & 5 & 20 & 16 & 20 & 14 & 11 & 2 & - & 11 & 24 \\
\hline Eggerella advena...$\ldots \ldots \ldots \ldots \ldots$ & 4 & 38 & 44 & 52 & 49 & 18 & 23 & 8 & 5 & 17 \\
\hline Elphidium oregonense .............. & 2 & $x$ & $x$ & $x$ & $x$ & - & - & - & - & - \\
\hline Quinqueloculina cf. seminula $\ldots$ & 2 & 2 & $\times$ & - & $x$ & - & - & - & - & - \\
\hline Lagenammina lagenarium .......... & - & $x$ & 1 & 1 & 3 & $x$ & $\times$ & - & 一 & - \\
\hline Textularia earlandi.................... & - & $\times$ & 2 & $x$ & 1 & 6 & 7 & 1 & - & $x$ \\
\hline Trochammina charlottensis $\ldots . . .$. & - & $x$ & - & 1 & $x$ & - & 2 & - & 2 & 一. \\
\hline Buliminella elegantissima $. . . \ldots . .$. & - & $x$ & 2 & 2 & $x$ & - & $x$ & - & 1 & $x$ \\
\hline Streblus japonicus ................. & - & $x$ & - & $x$ & $x$ & - & - & - & - & - \\
\hline Trocchammina squamata stellata & - & - & $x$ & $x$ & $\times$ & 8 & 4 & 6 & 8 & 3 \\
\hline Nonionella stella $\ldots \ldots \ldots \ldots \ldots \ldots \ldots$ & - & - & 1 & $x$ & $x$ & 39 & 47 & 7 & 48 & $x$ \\
\hline Epistominella tamana $\ldots \ldots \ldots \ldots \ldots$ & - & - & $\times$ & - & $\times$ & 7 & 4 & 7 & 2 & 8 \\
\hline Reophax communis ................... & - & - & $\times$ & - & - & - & 2 & 2 & - & 2 \\
\hline Involutina cf. minutissimum..... & - & - & - & $x$ & - & - & - & - & - & - \\
\hline Nonion cf. manpukujiense …...... & 一 & - & $x$ & $x$ & $x$ & - & - & - & $\dot{-}$ & - \\
\hline Trochammina pacifica.......... & - & - & - & - & - & 1 & $x$ & $x$ & $x$ & 3 \\
\hline Goësella flintii ......................... & - & - & - & - & - & 1 & $x$ & - & - & - \\
\hline Fissurina laevigata $\ldots \ldots \ldots \ldots \ldots \ldots$ & - & - & - & - & - & 1 & $x$ & 一 & - & - \\
\hline Haplophragmoides bradyi .......... & - & - & - & - & - & $x$ & $x$ & - & - & $x$ \\
\hline Uvigerina cushmani ............... & - & - & - & - & - & $x$ & $x$ & 1 & 2 & 16 \\
\hline Alveolophragmium crassimargo & $\dot{-}$ & - & - & - & - & $x$ & 1 & $x$ & - & $x$ \\
\hline Cassidulina nörvangi.............. & 一 & - & - & - & - & $x$ & - & 2 & 9 & 9 \\
\hline Glandulina laevigata $. . . . \ldots \ldots \ldots . . .$. & - & - & - & - & - & $x$ & $x$ & $x$ & - & - \\
\hline Cassidulina subglobosa........... & - & - & 一 & - & - & $x$ & - & - & $\times$ & - \\
\hline Lagena mollis $\ldots . . . . . . . . . . . . . . . . .$. & - & - & - & - & - & - & $x$ & - & - & $x$ \\
\hline Lagena striata.................... & - & - & - & - & - & - & $x$ & - & - & - \\
\hline Virgulina sp. $. . . . \ldots \ldots \ldots \ldots \ldots . . . . . .$. & - & - & - & - & - & - & $\times$ & $\times$ & - & $x$ \\
\hline Haplophragmoides (?) sp.......... & - & - & - & - & - & - & $\times$ & $x$ & - & - \\
\hline Gyroidina cf. soldanii …......... & - & - & - & - & - & - & $x$ & - & - & - \\
\hline Ammotium cassis $\ldots . . . . . . . . . . . . . .$. & - & - & 一 & - & - & - & $x$ & $x$ & - & - \\
\hline Asterigerinata cf. pacifica …..... & - & - & - & - & - & - & - & $x$ & $x$ & - \\
\hline Reophax scorpiurus ................... & - & - & - & - & - & - & 一 & $\times$ & - & $\times$ \\
\hline Nonion labradoricum $\ldots \ldots \ldots \ldots \ldots$ & - & - & - & - & - & - & - & - & - & $\times$ \\
\hline Elphidium bartletti $\ldots \ldots \ldots \ldots \ldots \ldots$ & 一 & - & - & - & - & - & - & - & - & $x$ \\
\hline Quinqueloculina cf. elongata...... & - & - & - & - & - & - & - & - & - & $x$ \\
\hline Cassidulina cf. laevigata $\cdots . . . . .$. & - & - & - & - & - & - & - & - & - & $x$ \\
\hline Benthonic population in $10 \mathrm{gr}$ & 56 & 1130 & 912 & 666 & 550 & 880 & 688 & 1680 & 164 & 1170 \\
\hline Planktonic population in $10 \mathrm{gr}$ & 3 & 3 & 8 & 2 & 10 & 0 & 0 & 10 & 5 & 20 \\
\hline
\end{tabular}


(Norman) and Ammotium cassis (PARKer) appear only in Fauna 3.

Fauna $3 \mathrm{~A}$ is characterized by the predominance of Nonionella stella CusHMAN \& MOYER. Eggerella advena CUSHMAN is also dominant. Epistominella tamana (KUWANO), Trochammina squamata stellata HÖGLUND, Textularia earlandi PARKER, Elphidium clavatum CUSHMAN and Buccella frigida (CUSHMAN) are important members.

The boundary at $c a .75 \mathrm{~m}$ is tentative since only one sample is available to establish Fauna 3B. The boundary is based upon :

1) Uvigerina cushmani ToDD, Cassidulina nörvangi Thalmann become dominant suddenly.

2) Nonion labradoricum (DAwson), Elphidium bartletti CuSHMAN, Quinqueloculina sp. cf. Q. elongata and Cassidulina $\mathrm{sp}$, cf. C. laevigata D'OrBIGNY, though the occurrences of them are rare, appear only in Fauna 3B.

Fauna $3 \mathrm{~B}$ is represented by only one sample and more materials are necessary to ascertain this fauna. The deep limit of this fauna is unknown. The fauna is characterized by the abundance of Uvigerina cushmani Tond which is considered to be a deep water species. Elphidium clavatum Cushman and Eggerella advena CusHMAN are abundant as in Fauna $3 \mathrm{~A}$.

As is mentioned in the chapter on the hydrography, there is a distinct boundary at $c a .50 \mathrm{~m}$ in depth, and there is another boundary at $c a .25 \mathrm{~m}$. These two boundaries appear to be well represented by benthonic Foraminifera assemblages. The boundaries also appear to be represented by planktonic organisms. MOTODA and ANRAKU (1952) studied the vertical distribution of plankton at the mouth of Funka Bay and found that warm-water species were concentrated in upper $30 \mathrm{~m}$ of water, Paracalanus parvus, a shallow-water copepod, disappeared at $50 \mathrm{~m}$, and Limacina helicina began to appear at $30 \mathrm{~m}$ and suddenly became less abundant at $50 \mathrm{~m}$. Thus physical (Hidaka, 1934 ; Uda, 1938), chemical (Matsudatra and Mizuuchi, 1934) and biological (MOTODA and ANRAKU, 1952) data appear to support the results obtained by the writer in studying benthonic Foraminifera.

Interpretation of these Foraminifera assemblages or boundaries is, for the time being, difficult since the oceanographic data of this area is very scarce. The $20 \mathrm{~m}$ boundary may represent the base of the turbulent zone, or the base of the upper water which is, though apparently of Oyashio type, a mixture of Oyashio and Tsugaru Currents. The $50 \mathrm{~m}$ boundary may represent the base of the seasonal thermocline. The presence of such arenaceous species as Haplophragmoides bradyi (ROBERTSON), Alveolophragmium crassimargo (NORMAN) and Ammotium cassis (PARKER) in Fauna $3 \mathrm{~A}$ and $3 \mathrm{~B}$ suggests that the water mass deeper than $c a .50 \mathrm{~m}$ may represent the Intermediate Water.

Total benthonic population at Station 4 and 11 is much smaller than that at other stations. This is because the sediment at Station 4 is coarser than at other sta. tions, and the sediment at Station 11 contains abundant pumice grains. In general 
it appears that the more pumice grains in sediment the less the benthonic population is.

\section{Brief Taxonomic Notes}

Elphidium planum HUSEzIMA \& MARUHASI is a synonym of Elphidium subarcticum Cushman.

- Elphidium ezoense ASANO is a synonym of Elphidium oregonense CUSHMAN \& GRANT. Cribroelphidium arcticum TAPPAN is a synonym of Elphidium bartletti CusHMAN.

Alveolophragmium ochotonensis STSCHEDRINA is a synonym of Alveolophragmium crassimargo (NORMAN).

Uvigerina cushmani TODD may be a synonym of Uvigerina yabei AsANo, but it is not sure.

\section{REFERENCES}

Central Meteorological Observatory., 1950-1952. The results of marine meteorological and oceanographical observations, Nos. 1-7.

CUshman, J. A. 1940. Foraminifera; their classification and economic use, 3rd ed. Harvard University Press.

HIDAKA, K. 1934. Results of the observations on board R.M.S. "Syunpu Maru" in FunkaWan (Volcanic Bay), Hokkaido. (Aug. 1932). Journal of Oceanography, Vol. 6, no. 2, pp. 209240.

Japanese Hydrographic Office. 1946-1950. Oceanographic and meteorological observation at the stations.

MatsudairA, Y. \& MizuUChI, Y. 1934. Results of the observations on board R.M.S. "Syunpu Maru" in Funka Wan (Volcanic Bay), Hokkaido. (Aug. 1932). Journal of Oceanography, Vol. 6, no. 2, pp. 209-240.

Motoda, S. \& ANRaku, M. 1952. Observations on the plankton of Funka-Bay, Hokkaido. I. Vertical distribution of plankton at the mouth of the bay in August, 1950. Bull. Hokkaido Fisher. Res. Lab. Fisheries Agency, No. 5, pp. 17-20.

OWADA, M. 1954. The planktological and oceanographical conditions in the vicinity of FunkaBay (Volcanic Bay). Journ. Oceanogr. Soc. Japan, Vol. 9, no. 3, pp. 181-184.

UDA, M. 1938. Hydrographical fluctuation in the north-eastern sea region adjacent to Japan of north Pacific Ocean. Journ. Imp. Fish. Exper. Stat. Tokyo, Japan, No. 9, pp. 1-66. 